\title{
Advocate Anomalies in Money Laundring Practices in Indonesia: Analysis of Legal System Theory to Reporting Function in Government Regulation No. 43 Year 2015
}

Fauziah Lubis

\begin{abstract}
This study focuses on how anomalies advocate in money laundring practices in Indonesia by providing analysis of the law and reporting functions in government regulation No. 43 year 2015. Government Regulation No. 43 year 2015 is obliging the advocate profession to report suspicious financial transactions to the PPATK. This research also aims to determine the implementation of PPATK in carrying out its duties as one of the institutions that supervise the travel flow of financial funds in Indonesia, especially from various professions that have potential harm to the country, Besides, also know the policies and applications and attitudes of the advocacy profession who are often involved in the practice of money laundring, as well as the conflict of interest that occurs from the PPATK with the advocate. This certainly caused PPATK to see the flow of funds often clash between the law and government regulation number 43 year 2015. With this law the confidentiality of the advocate profession has been assured, because the advocate has an internationally known lawyer-client privilege principle, which is not to convey the Considered confidential (confidential) except for the permits or orders of his clients so feared from this clash suspected the occurrence of business to do money laundring practices.
\end{abstract}

Keywords--- Money Laundring, Advocate, PPATK, PP Number 43 Year 2015.

\section{INTRODUCTION}

In the recommendation 12 and the recommendation 16 FATF (financial Action Task Force) on Money Launderin has classified the reporting party into three categories, namely financial institutions, non-financial institutions, and professions (including professions in Law). It is therefore understandable that the true international world wants the legal professions to be the reporting party for suspicious financial actions. At the same time, PP No. 43 year 2015, One of the advocate profession is classified as the reporter who must submit a report suspicious financial transactions to the PPATK. It is intended to release the advocates from the form of criminal acts of money laundering or money laundering.[1]

Money Laundering is a process of changing profits from the results that are obtained by resisting the law into financial assets that are visible from legitimate sources. As a form of a series of activities by a person or organisation against money originating from a crime, with the intent to conceal or disguise the origin of the money from the government or competent authorities, take action Against criminal acts by primarily putting the money into the financial system, so that money can be withdrawn from the financial system as a halal money(Lilley 2003).In the Law enforcement context, the term Money Laundering It is not a simple concept, but complex because the problem

Fauziah Lubis, Faculty of Sharia, Universitas Islam Negeri Sumatera Utara, Medan, Indoenesia. E-mail: fauziahlubis@uinsu.ac.id 
is so complex that it is quite difficult to formulate the legal delic (criminalization) objectively and effectively. This is reflected by its considerable and varied sense of understanding.[2]

Advocates can not only be arranged through PP alone. Preferably, in accordance with the clearly stated in the Advocate ACT, such exceptions are governed in detail in the act for the sake of legal certainty for all parties, especially the legal profession of advocates and not with a lower level PP of the Act. Based on the explanation above, it can be understood that necessary attempts to analyze the theory of the legal system to the reporting function in government Regulation number 43 year 2015.[3]

In Philosophi advocate profession in the context of the prevention of money laundering is not to win or defeat clients who are troubled by law, but the enforcement of justice that money laundering crimes give great impact to the community As well as to the country. Saving state money is an important issue that must be enforced in addition to preventing this crime from expanding and negatively impacting.[4][5][6]

\section{Methodology}

In conducting a legal study can not be missed by the use of research methods to analyse the problems raised. Research is a scientific activity based on certain methods, systematics and thinking that aims to study one or more of the specific legal symptoms, with the way to analyse them. In addition, a thorough examination of the legal fact is also held to try to solve the problems that arise in the symptoms.[7]

The type of legal research used in this article is a normative research method. In this legal research, often the law is conceptualed as what is written in legislation (law in Books) or the law conceptualed as a rule or norm and is the benchmark of human behaviour that is appropriate, so This research is very closely related to the library because it requires data that is secondary to the library(Ediwarman 2015).[8]

In normative research secondary data as a source of information, can be used as primary legal materials, secondary legal materials, and tertiary legal materials. The data retrieval and collection procedures in this research are conducted through Library research. The study of the literature is also conducted on written legal materials that are relevant to both primary, secondary and tertiary legal substances, as well as non-legal materials.[9]

Data analysis method used to draw conclusions from the research results that have been collected by using qualitative analysis. The research is based on existing regulations as the law of positive norms, while qualitative is intended to attempt to invention principles and information without the use of statistical formulation. While the use of numbers is only limited to a percentage number so that obtained a clear and thorough picture of the problem being researched. So that it can conclude the resolution of the problem in accordance with the legislation in the inductive way, in order to reach the final conclusion that can answer the problems examined in this article.[10]

Data analysis method is done by checking the collected data. Then, qualitative data analysis, i.e. the data obtained is arranged systematically then in a qualitative analysis in the form of rules. The legal analysis process is done to answer the problems examined in this article. 


\section{III.RESULT AND DiscuSSION}

The establishment of money laundering laws in Indonesia is not separated from the influence of FATF with various forms of pressure on Indonesia to immediately criminalize money laundering, such as: FATF puts Indonesia into a list of reviews and lists Non-Cooperative countries and Territories are accompanied by the threat of sanctions against Indonesia if they are not immediately compliant with the rules applied by the FATF. Finally, for the first time Indonesia did criminalize money laundering by law No. 15 year 2002(Armanda and Jamaan 2015).

Often the case is the funds deposited in the bank on behalf of the advocate, and the advocates who deposit funds in the bank in the name of his client cannot be forced by the competent authorities to reveal his client's identity. Consequently, an advocate cannot be asked for a description of his relationship with his client (Adjie 2001). Therefore, one of the driving factors is the way money laundring, although it has been regulated in law number 8 year 2010 in detail on the issue of prevention and eradication of criminal acts money laundring It is still a constant occurrence, colliding with the provisions of the law stating that the relationship of lawyer or advocate with the client is a confidentiality relationship that should not be disclosed.

Advocates who have been entered as the reporting party in government Regulation No. 43 year 2015 is a form of potential money laundring in this profession. Pursuant to article 8 of the Government's regulation shall be mandatory advocates Report if there is suspicious financial transaction to the PPATK. Then PPATK conducts the search of the identity of the perpetrator, colleagues, family to business associates until the discovery of the perpetrator with the term follow the money suspicious financial transactions according to the law number 8 Years 2010 on the prevention and Eradication of Money laundering crimes.

According to government Regulation No. 43 year 2015 on reporting Parties in the prevention and eradication of money laundering crimes with suspicious financial transactions are:

1) Financial transactions that deviate from the profile, characteristics, or customs of the transaction pattern of the relevant service user;

2) A financial transaction by an appropriate service user is alleged to be conducted in order to avoid reporting the relevant transaction which must be done by the reporter in accordance with the provisions of the laws governing the Prevention and eradication of Money laundering crimes;

3) Financial transactions conducted or void by the use of wealth allegedly derived from criminal acts; Or

4) The financial transaction requested by the PPATK to be reported by the reporting party for involving the property is allegedly derived from a criminal offence.

\section{IV.DISCUSSION}

\section{Advocate profession and involvement in Money Laundring}

The Advocate profession in its early history is called the terms "Advocatus Diaboli/Promotor Fidei" (Devil Advocate) and "Advocatus Iustitia/promoter of the Causa terminology." "(The Lord'S Advocate). The term develops in the tradition of Roman law whereby evil advocates attack all arguments of the Church advocate (God). There is another opinion that the word advocate itself comes from the Latin language "Advocare" and in English is called 
"Advocate". The historical advocate term of ancient Rumawi later evolved into a term of attorney, lawyer, advocate, legal advisor, legal consultant and others as the profession was deemed noble in law enforcement. The difference in the mention of this variation is especially for Indonesia because some laws use different terms. Advocate in fact is a profession quite difficult to be played. Because advocates carry on the profession of duty to firm justice based on the law for the benefit of the Seeker of Justice Society high moral, noble and noble and in carrying out its duty to uphold the law, CONSTITUTION 1945, the Code of Ethics Advocate and oath of office

Advocate in carrying out his profession is to uphold justice based on the law to the interests of the Seekers of public justice, providing legal services both in the judiciary and outside the Court of Good legal consultation, legal aid, exercising power, represent, accompany, defend and perform other legal action acts for client's legal interests. All of this must meet the requirements under LAW No. 18/2003 on advocate.

Reviewing the facts above, it can be noted that the legal professions that include lawyers, notary, PPAT, and so forth are currently very prone to involve in the action of money laundering. Such a thing is natural considering that the professions have skilled skills in the field of law. So that their services should be used to enforce the law but are misused in terms of lawlessness. In line with the above, Peter Reuter insists that lawyers become common agents in the Money laundering scheme(Utama 2006).

Post-Birth of PP number 43 year 2015 about the reporters in the prevention and Eradication of the Laundering Criminal act is an obstacle for the profession. In PP No. 43 year 2015, One of the advocates profession is classified as a reporter who must submit a report suspicious financial transactions to the PPATK. This PP resulted in a professional obligation to report to the PPATK regarding suspicious financial transactions in the interest of or for and on behalf of the service user as contained in article 3 and article 8 paragraph (1). The result of a criminal offense by means of protection behind the provisions of confidentiality of profession relationship with service users is governed in accordance with the provisions of legislation.

\section{Money Laundring from the legal perspective}

In the context of law enforcement, the term money laundering is not a simple concept, but complex because the problem is so complex that it is quite difficult to formulate the legal delic (criminalization) Objective and effective manner. This is reflected by its considerable and varied sense of understanding. The relative limitation of understanding is also found in the countries that both have the provisions of the Anti-Money Laundering Act.

Criminal offence Money laundring is a transnational crime that of course can not be done by any person. Money laundring criminal acts are also often called white collarcrime, because the culprit is a professional or person who has a position and authority. So criminal offense Money laundring is a crime that should be eradicated. Therefore, Indonesia has criminalized the money loundering Criminal act or commonly referred to as "money laundering" with the beginning of the establishment of Law no. 15 of 2002 concerning MONEY Laundering Crimes (law Tppu), and as time has been revised into law number 25 of 2003, and re-updated with law number 8 of 2010 concerning the prevention and eradication of Money laundering crimes applicable to date. 
The term money laundering was previously used only for financial transactions relating to organized crime. But now the understanding is expanded by government regulators, such as (United States Office of the Controller of the Currency) includes any financial transactions that generate assets or values as a result of illegal actions, such as taxafation. Money laundering practices can be done by individuals, small and large businesses, corrupt officers, organized crime members such as drug traffickers and mobsters. Money laundering provides direct or indirect impact on economic activities, especially regarding financial institutions. Therefore, the Government must be able to prevent this money laundering practice and to fix the Money Laundering criminal Act to accommodate all criminal acts of money laundering in Indonesia in order to enforcement of legal supremacy(Mathilda 2013).Money Laundering Criminal acts can use the services of professions asGatekeeperin money laundering. Advocate, notary, PPAT is obliged to be the reporter for suspicious financial transactions in the Pension criminal act for various reasons. Basically the formulation is concerned a process of money laundering obtained from the crime and washed through a financial institution (bank) or financial services provider, so that the money that is unclean to get the appearance as money Legitimate or lawful(Eleanora 2019).

\section{Disadvantages of PPATK as a Money Laundring supervisor due to Conflict of Interest}

In order to prevent and eradicate money laundering crimes, the Financial transaction reporting and Analysis Center (PPATK) is formed by an independent agency directly responsible to the president. PPATK is essentially a financial intelligence unit, generally known as the Financial Intelligence Unit (FIU) (Husein 2003). The importance OF PPATK is underpinned by the realization that to combat money laundering requires special skills. The establishment of the Financial Intelligence unit in charge of accepting and processing financial information from financial services providers should be seen from the backdrop of the increasing demand for the importance of such specialized expertise.

There are no default rules governing the shape and role that FIU should run. Recommendations published by the Caribbean Drug Money Laundering Conference, for example, only require the need for a special body responsible for conducting investigations, prosecution and foreclosures. The FATF recommendation only mentions the need for competent authorities in charge of receiving reports from financial services providers. While the European Money Laundering Directive refers to the competent body combating Money Laundering and requiring EU members to guarantee that the agency has the authority to request a report from Financial services providers. The Egmont Group (TEG), a LOOSE group of FIU, provides a general defendant about FIU: "A Central National agency responsible For receiving (and as Dayagel permitted, requesting), analyzing and disseminating to the competent authorities, disclosures of Financial Information: (1) concerning Suspected proceeds from crime, or (2) required by national legislation or regulation, in order to counter money laundering "(Stessens 2000).

The above definition contains three basic functions owned by all types of FIU i.e. each FIU has a function:

1) As a repository It means that the unit is an information center about Money laundering. FIU not only receives information about financial transactions but FIU can also control the information.

2) The function of analysis means to process the information that FIU receives and add value to that information. 
The performance of this function depends on the source of information that can be accessed by FIU. In processing the information of the authorized FIU decides whether a valuable information to be acted upon becomes an investigation/investigation. FIU's last function is as a clearing house. In this capacity FIU facilitates the exchange of information about unusual financial transactions or suspicious financial transactions. The exchange of this information may be related to information in any form (individual or general) and may take place with various partners in and outside the country.

In Indonesia we have PPATK as a financial intelligence Unit, as an independent institution responsible to the president. When viewed from his duties and authorities, PPATK belongs to the category of administrative model. This administrative Model more serves as an intermediary between the community or the financial services industry with law enforcement institutions. Incoming reports were analyzed by PPATK and then reported to law enforcement institutions, namely the police and prosecutors. According to article 26 and article 27 of the Money Laundering Law of the PPATK duties, among others: collecting, storing, collecting, analyzing, evaluating the information obtained under this law, by spreading it, making Guidelines on the procedure for reporting suspicious financial transactions, providing advice and assistance to other competent authorities on information obtained in accordance with the provisions of the law, providing recommendations to the government In connection with the prevention and eradication of Money laundering crimes, report the results of analysis of financial transactions that indicate money laundering crimes to the police for the benefit of the investigation and prosecutors to The interests of prosecution and supervision, making and delivering reports on the analysis of financial transactions and other activities periodically to the President, the DPR and the competent institution supervising the financial services provider (PJK).

The authority of PPATK among others: requesting and receiving reports from the CHD, requesting information on the development of the investigation or prosecution of money laundering crimes that have been reported to investigators or prosecutors. From these duties and authorities there are two main tasks that stand out in relation to the eradication of money laundering crimes, the task of detecting the occurrence of money laundering crimes and the task of assisting law enforcement related to Money laundering and criminal acts that are devoing them (predicate crimes). In order to detect money laundering crimes against Money Laundering Law, PPATK created various reports on the issue of financial flows in Indonesia, one of the parties related to the mandatory status of reporting His finances are advocate. Advocate's obligation to perform reporting on financial transaction reporting and Analysis Center (PPATK) related to suspicious financial transactions gets several exceptions. Such exceptions are in government Regulation No. 43 year 2015 on reporting Parties in the prevention and eradication of money laundering crimes, including:

a) Ensure the legal position of service users.

b) Handling a lawsuit, arbitration, or alternative dispute resolution.

With the existence of article 8 paragraph 2 Government Regulation No. 43 year 2015, precisely provides a wide space for advocate as one of four (4) law enforcement pillars to develop the reporter's profession as a form of preventing financial transactions that are Suspicious. 
Every transaction that is above Rp. 500.000.000,-(five hundred million rupiah) must be traced by PPATK, with the intention of the flow of funds from where to WHO. Traced by the flow of money, in what form, because it is feared to be in the criminal act of Money Laundering (TPPU). Ensure the legal position of service users in this government regulation is the advocate conducting a legaldue diligence (legal audit) of a company or the object of the transaction in accordance with the purpose transactions, to obtain information or fact material that can describe the condition of a company or a transaction object. Therefore, the Advocate in conducting actions on behalf of clients in the form of financial activities must be reported to the financial transaction reporting and Analysis Center (PPATK).

Advocate acting on behalf of clients in conducting legal activities both litigation and non litigation is excluded for reporting on the financial Transaction Reporting and Analysis Center (PPATK), as it is protected by regulatory Perundang-Undanganyang where advocates must maintain the confidentiality of its clients. With the integrated head of PPATK regulation number 11 year 2016, there is also a provision that the profession which belongs to the reporting party in government Regulation No. 43 year 2015 shall decide business relationship with service users if:

a) Service users refuse to adhere to the principle of recognizing service users; Or

b) The profession doubts the correctness of information submitted by service users. And the profession is obliged to report it to PPATK regarding the act of termination of such business relationship as TKM.

The obligation to report to the profession raises legal issues juridically. The formulation of the reporting party stipulated in article 17 paragraph (1) of Law No. 8 of 2010 concerning the prevention and Eradication of Money Laundering (LAW PPTPPU) expressly determines only the financial services provider and the goods provider and/or Other services. The obligation for the profession is interpreted from the clause. The weakening cause of PPATK supervision to carry out its duties, in order to provide the right logging on the number of financial transaction reports has constraints, such as in processing the entry of financial transactions that are on the Certain professions, such as the finances of advocates protected by law, always relate the confidentiality of the advocates to its clients. Therefore, the path of confidentiality can be made an opportunity to avoid the transparency of funds from clients.

\section{ConCLusion}

Money Laundering is a process of changing profits from the results that are obtained by resisting the law into financial assets that are visible from legitimate sources. As a form of a series of activities by a person or organisation against money originating from a crime, with the intent to conceal or disguise the origin of the money from the government or competent authorities, take action Against criminal acts by primarily putting the money into the financial system, so that money can be withdrawn from the financial system as a halal money.

One of the motivating factors of money laundring Although it has been regulated in Law number 8 of 2010 in detail on the issue of prevention and eradication of criminal offense money laundring still Lively occurs, colliding with the provisions of the law stating that the relationship of lawyer or advocate with the client is a confidentiality relationship that should not be disclosed. 
Post-Birth of PP number 43 year 2015 about the reporters in the prevention and Eradication of the Laundering Criminal act is an obstacle for the profession. In PP No. 43 year 2015, One of the advocates profession is classified as a reporter who must submit a report suspicious financial transactions to the PPATK. This PP resulted in a professional obligation to report to the PPATK regarding suspicious financial transactions in the interest of or for and on behalf of the service user as contained in article 3 and article 8 paragraph (1). The result of a criminal offense by means of protection behind the provisions of confidentiality of profession relationship with service users is governed in accordance with the provisions of legislation. The obligation to report on the profession raises legal issues juridically, due to legislation governing confidentiality issues with advocates and their clients, causing PPATK not to oversee the financial flow of funds Maximum.

\section{REFERENCES}

[1] “Adjie, Indriyanto Seno. 2001. Prospektif Hukum Pidana. Jakarta: CV Rizkita.”

[2] "Armanda, Rizky, and Ahmad Jamaan. 2015. 'Pengaruh Financial Action Task Force Nn Money Laundering Terhadap Terbentuknya Undang-Undang Pencucian Uang Di Indonesia.’ JOM Fakultas Ilmu Sosial Dan Politik 2 (2): 1-13.”

[3] "Ediwarman. 2015. Monograf Metodologi Penelitian Hukum (Panduan Penulisan Skripsi, Tesis Dan Disertasi). Medan: PT Sofmedia.”

[4] “Eleanora, Fransiska Novita. 2019. ‘Tindak Pidana Pencucian Uang.’ Jurnal Hukum 26 (2): 640-53.”

[5] "Husein, Yunus. 2003. 'PPATK: Tugas, Wewenang Dan Peranannya Dalam Memberantas Tindak Pidana Pencucian Uang.’ Jakarta.”

[6] "Lilley, Peter. 2003. Dirty Dealing: The Untold Truth about Global Money Laundering, International Crime and Terrorism. 2nd ed. London and Sterling: Kogan Page Limited."

[7] "Mathilda, Fiorida. 2013. 'Tindak Pidana Pencucian Uang Di Bidang Perbankan.’ SIGMA-Mu 5 (2): 5567."

[8] "Sjahdeini, Sutan Remy. 2004. Seluk Beluk Tindak Pidana Pencucian Uang Dan Pembiayaan Terorisme. Jakarta: PT Pustaka Utama Grafiti.”

[9] "Stessens, Guy. 2000. Money Laundering A New International Law Enforcement Model. Cambridge: Cambridge University Press.”

[10] “Utama, Paku. 2006. “Gatekeepers’ Roles as a Fundamental Key in Money Laundering.” Journal Indonesia Law Review 6 (2): 180-206. https://doi.org/http://dx.doi.org/10.15742/ilrev.v6n2.215.” 